\title{
Hypotensive Potential of Desmodium Adscendens on Cardiovascular Functions
}

\author{
Seriki SA* \\ Department of Physiology, College of Medical Sciences, Edo University, Iyamho, Nigeria \\ *Corresponding author: Seriki SA, Department of Physiology, College of Medical Sciences, Edo University, Iyamho, Nigeria
}

\begin{abstract}
Backgrounds: Desmodium adscendens is one of the medicinal herbs used in the management of some medical conditions in recent times. The current study investigates the effects of aqueous leave extract of Desmodium adscendens on the serum levels of Sodium, Chloride, Potassium, and Bicarbonate ions, and by inference on the cardiovascular function in healthy wistar rats.

Method: Twenty-four (24) wistar rats grouped into four $(n=6)$ were used for the research. Group 1 served as control, while Groups 2, 3, and 4 were treated orally with low, median and high doses of the extract of $D$ adscendens for four weeks, after which blood was collected separately from each group and the serum level of the electrolyte determined by appropriate methods and comparison made with the control group and among the groups.

Results: There was significant decrease $(\mathrm{P}<0.05)$ in serum concentration of Sodium, Chloride and Bicarbonate ions, and an increase in Potassium ion.

Conclusion: The decrease in serum concentration of $\mathrm{Na}^{+}, \mathrm{Cl}^{-}, \mathrm{HCO}_{3}{ }^{-}$indicates that the extract has the potential to lower blood pressure, and that may be attributed to the active phytochemical constituents present in the leaves. Therefore $D$. adscendens leaf has beneficial hypotensive potential on cardiovascular functions.
\end{abstract}

Keywords: Serum electrolytes; Hypotensive potentials; Cardiovascular function, Desmodium Adscendens

\section{Introduction}

Medicinal values of several plants have over time provided alternatives to conventional medicines in the treatment of many ailments, and importantly, at a cheaper rate, especially in developing nations.

\section{Desmodium adscendens}

Desmodium adscendens is one among such useful medicinal plants that have recently gained the attention of many researchers. It is a rain forest herb that has been traditionally used by the natives for a wide variety of medical conditions including muscle cramp, tendon, spinal pain, bronchitis, epilepsy and some central nervous system disorders. Other uses include rheumatism, jaundice, hepatitis, protection of liver from cirrhosis, asthma (owing to its bronchial dilating effects), allergic symptoms and eczema. It is also a very potent natural antispasmodic agent [1]. It is of the Family"Fabaceae"; and genus-Desmodium. Common names of Desmodium adscendens are Beggar- lice, Beggar weed, Tick Clover, Tick trefoil [1].

\section{Serum electrolytes}

Serum electrolytes are salts and minerals, such as sodium, potassium, chloride and bicarbonate, which are found in the blood, and conduct electrical impulses in the body. An electrolyte test can help determine whether there is an electrolyte imbalance in the body or not. Electrolyte disorders are a potentially hazardous complication frequently seen in patients with heart failure. They occur when the levels of electrolytes in the body are either too high or too low. Electrolytes need to be maintained in an even balance for the body to function properly. Severe electrolyte imbalances can cause serious problems such as coma, seizures, and cardiac arrest [2]. The imbalance may result from pathological alterations leading to stimulation of the Renin-Angiotensin-Aldosterone System (RAAS), sympathoadrenergic stimulation, a neurohormonal 
activation, and possibly due to the complications of therapy with diuretics, cardiac glycosides or ACE inhibitors [2]. Electrolytes abnormalities could be severe and cause life threatening conditions that could affect prognosis and outcome of disease in different clinical settings. Alterations in the levels of serum electrolytes have also been known to increase cardiovascular morbidity and mortality [2].

\section{Sodium ion}

Antidiuretic Hormone (ADH), also known as arginine vasopressin is a non-peptide hormone that regulates renal handling of free water. Alteration of the amount of water reabsorbed by the kidney has an important effect on serum sodium concentration. ADH is secreted by the neurons in the supra-optic and paraventricular nuclei of the hypothalamus, and its release is stimulated by hypovolemia, thirst, increased serum osmolality, and angiotensin II [3]. In the Renin-Angiotensin-Aldosterone System, renin from the kidney catalyzes the conversion of angiotensinogen to angiotensin I, which is further converted to angiotensin II (in the lungs), [3]. Angiotensin II, which is a vasoconstrictor is important in maintaining optimal perfusion pressure to end organs, especially when plasma volume is decreased. It also induces the release of aldosterone, ADH and (to a lesser extent) cortisol. Aldosterone is a hormone released from the adrenal cortex of the kidneys with mineralocorticoid actions, which affects the distal tubular reabsorption and retention of sodium rather than water [3].

\section{Potassium ions}

Potassium ions play an important role in regulation of the heartbeat and function of muscles. Normal serum potassium level=3.5-5.0mEq/L. Potassium, along with sodium is involved with regulation of water and acid-base balance in blood and tissue [4]. In mammals, the osmotic pressure and water distribution maintenance is the primary function of electrolytes like sodium and potassium. In addition, they play a role in maintenance of $\mathrm{pH}$, in oxidation reduction reactions, in heart muscle functioning and as co-factors for enzymes [5]. The body has two different mechanisms to restore potassium balance when the serum potassium concentration is high: by shifting the plasma potassium into cells, and by renal elimination [6].

\section{Chloride ion}

Chloride ion is the most abundant extracellular anion with a concentration of about $95-110 \mathrm{mmol} / \mathrm{L}$. It is passively absorbed from the upper small intestine. Chloride is primarily regulated by the renal proximal tubules, where it is exchanged for bicarbonate ions and passively follows sodium and water through during renal tubular reabsorption by the nephron. Chloride ion is influenced by the extracellular fluid balance and acid-base balance [7] Homeostatic mechanisms indirectly regulate Chloride ion through changes in sodium and bicarbonate. The physiological role of chloride is to balance out positive charges in the extracellular fluid and, by following sodium passively, it helps to maintain extracellular osmolality.

\section{Bicarbonate ion}

Bicarbonate ion is an intermediate form in the deprotonation of carbonic acid. It is a polyatomic anion with the chemical formula $\mathrm{HCO}_{3}^{-}$. It serves a crucial biochemical role in the physiological $\mathrm{pH}$ buffering system [8]. Bicarbonate $\left(\mathrm{HCO}_{3}^{-}\right)$is a vital component of the $\mathrm{pH}$ buffering system [8] of the human body (maintaining acidbase homeostasis). $70 \%-75 \%$ of $\mathrm{CO}_{2}$ in the body is converted into carbonic acid $\left(\mathrm{H}_{2} \mathrm{CO}_{3}\right)$, which is the conjugate acid of $\mathrm{HCO}_{3}^{-}$and can quickly turn into it. With carbonic acid as the central intermediate species, bicarbonate, in conjunction with water, hydrogen ions, and carbon dioxide forms the buffering system, which is maintained at the volatile equilibrium [8] required to provide prompt resistance to $\mathrm{pH}$ changes in both the acidic and basic directions. This is especially important for protecting tissues of the central nervous system, where $\mathrm{pH}$ changes too far outside of the normal range in either direction could prove disastrous. A higher serum bicarbonate concentration is associated with higher left ventricular mass, higher aortic pulse pressure and a higher risk of heart failure among non-users of diuretics [9].

\section{Method}

\section{Phytochemical analysis}

The ethanolic leaf extract of Desmodium adscendens was subjected to phytochemical analysis. $2 \mathrm{~g}$ of the crude extract was weighed and dissolved in $20 \mathrm{ml}$ of distilled. The solution was screened for the presence and absence of alkaloids, flavonoids, tannins, saponins, glycosides, reducing agents, polyphenols, anthraquinones, and phlobatanins following standard methods [10].

\section{Test for alkaloids}

Mayer's Test: $2 \mathrm{ml}$ of the filtrate and control solutions were measured with pipette into two separate test tubes. To the test tubes were added 3 drops of Mayer's reagent. The solutions were mixed and allowed to stand for $5 \mathrm{~min}$ and then observed for the presence of precipitate and color change.

Wagner's test: $2 \mathrm{ml}$ of the filtrate and control solutions were pipetted into two separate test tubes. To the test tubes were added 3 drops of Wagner's reagent. The solutions were mixed and allowed to stand for $5 \mathrm{~min}$ and then observed for the presence of precipitate and color change.

Dragendorrf's test: $2 \mathrm{ml}$ of the filtrate and control solutions were pipetted into two separate test tubes. To the test tubes were added 3 drops of Dragendorff's reagent. The solutions were mixed and allowed to stand for $5 \mathrm{~min}$ and then observed for presence of precipitate and color change. 


\section{Test for tannins}

i. $2 \mathrm{ml}$ of the filtrate and control solution were pipetted into two separate test tubes. To the test tubes were added 3 drops of $10 \%$ ferric chloride. The mixtures were observed for presence of precipitate and color change.

ii. $2 \mathrm{ml}$ of the filtrate and control solution were pipetted into two separate test tubes. To the test tubes were added 3 drops of $10 \%$ lead acetate. The mixtures were observed for presence of precipitate and color change.

\section{Test for flavonoids}

i. $2 \mathrm{ml}$ of the filtrate and control solutions were pipetted into two separate test tubes. To the test tubes were added 3 drops of $\mathrm{NaOH}$. The mixtures could stand for 2 min and then observed for presence of precipitate and color change.

ii. $\quad 2 \mathrm{ml}$ of the filtrate and control solutions were pipetted into two separate test tubes. To the test tubes were added 3 drops of $\mathrm{NaOH}$ and 3 drops of $0.5 \mathrm{NHCl}$. The mixtures were observed for presence of precipitate and color change.

\section{Test for saponins}

Emulsifying test: $2 \mathrm{ml}$ of the filtrate and control solution were pipetted into two separate test tubes. To the test tubes were added 3 drops olive oil and the mixture shaken vigorously. The mixtures were observed for presence of brown emulsion.

Frothing test: $1 \mathrm{ml}$ of the filtrate and control solution were pipetted into two separate test tubes. To the test tubes were added $4 \mathrm{ml}$ distilled water. The mixture was shaken vigorously and then observed for presence of frothing.

\section{Test for anthraquinone}

$0.1 \mathrm{~g}$ of the crude extract was dissolved in $10 \mathrm{ml}$ concentrated chloroform. The solution was filtered and used for this test. To $5 \mathrm{ml}$ of filtrate and control solution in separate test tubes was added $5 \mathrm{ml}$ ammonia solution. The mixtures were shaken vigorously. The mixtures were observed for presence of precipitate and color change.

\section{Test for glycoside}

To $2 \mathrm{ml}$ of filtrate and control solutions in separate test tubes were added $2 \mathrm{ml}$ of Fehling I and Fehling's II solutions. The solutions were mixed thoroughly and boiled in a water bath for $2 \mathrm{~min}$. The mixture was observed for the presence of precipitate and color change.

\section{Test for terpenes}

$0.1 \mathrm{~g}$ of the crude extract was dissolved in $10 \mathrm{ml}$ concentrated chloroform. The solution was filtered and used for this test. To $1 \mathrm{ml}$ of filtrate and control solutions in separate test tubes were added
$1 \mathrm{ml}$ acetic anhydride. The solutions were mixed thoroughly with a glass rod. The test tubes were then placed in slanting positions and $1 \mathrm{ml} \mathrm{H}_{2} \mathrm{SO}_{4}$ was added to the side of each test tube into the mixture. The junction of the two liquid layers was observed for the presence of color change.

\section{Experimental Animals}

A total of forty 24 adult male albino Wistar rats weighing between 120-160g were used for this experiment. The animals were obtained from the faculty of Basic medical science animal house, University of Calabar. The rats were maintained on standard rat feed (growers feed) and tap water available all through the period of experiment. The animals were maintained at an ambient temperature between $28-30$ 으, humidity of $55 \pm 5 \%$, and standard (natural) photoperiod of approximately 12 hours of light (06:30 hour-18:30 hour) alternating with approximately 12 hours of darkness (18:30 hour-06:30 hour). The rats could get familiarized with the environment for a period of 7 days before treatments commenced.

\section{Preparation of Extract}

Two (2) grams of the aqueous leaves extract of Desmodium adscendens was dissolved in $10 \mathrm{ml}$ of distilled water as follows; $2 \mathrm{~g}=10 \mathrm{ml}$ of water $(200 \mathrm{mg}=1 \mathrm{ml})$. If $200 \mathrm{mg}=1 \mathrm{ml}$, therefore, $300 \mathrm{mg}=1.5 \mathrm{ml}, 450 \mathrm{mg}=2.25 \mathrm{ml}$, and $600 \mathrm{mg}=3 \mathrm{ml}$ of water. Volume per animal was determined as follows; for the low dose treated group, $300 \mathrm{mg}$ of extract was dissolved in $1.5 \mathrm{ml}$ of water. A rat in the low dose group with a body weight $120 \mathrm{~g}$ received $36 \mathrm{mg}$ of the extract. If $300 \mathrm{mg}$ of extract was dissolved in $1.5 \mathrm{ml}$ of water, $36 \mathrm{mg}$ of the extract will be dissolved in $0.18 \mathrm{ml}$ of water. Therefore, an animal in the low dose group with a body weight of $120 \mathrm{~g}$ will receive $0.18 \mathrm{ml}$ of the extract daily all through the treatment period. Same was applicable to all the experimental animals all the extract treated groups. Extract administration was done orally with the aid of an orogastric cannula and treatment lasted for four (4) weeks.

\section{Experimental Design}

At the end of the acclimatization period, the animals were randomly assigned into four (4) groups, $n=6$, as follows.

i. Control (Received normal rat chow and tap water).

ii. Low dose treated group (Received low dose of extract $(300 \mathrm{mg} / \mathrm{kg})$.

iii. Median dose treated group (Received middle dose of extract $(450 \mathrm{mg} / \mathrm{kg})$.

iv. High dose treated group (Received high dose of extract (600mg/kg).

Treatments lasted for a period of four (4) weeks, all animals had free access to fed and water and libitum. 
Collection of blood samples: At the end of treatment period, animals from all the experimental groups were sedated and made unconscious using chloroform anesthesia. Blood samples from each rat was collected via cardiac puncture [11] into EDTA and plain sample bottles for the estimation of hematological and biochemical parameters.

Analysis of serum: Serum from the different groups was analyzed for the following Antioxidant Enzymes; Super Oxide Dismutase (SOD), Catalase (CAT), Glutathione Peroxidase (GPx), and Marker of Lipid Peroxidation (MDA)

\section{Results}

Comparison of serum electrolytes in the different experimental groups

\section{Sodium ion concentration $\left(\mathrm{Na}^{+}\right)$}

Desmodium adscendens extract caused significant $(\mathrm{p}<0.05)$ decrease in $\mathrm{Na}^{+}$concentration in the three groups given low, median and high doses of the extract when compared with the control $(139.67 \pm 0.48 \mathrm{mmol} / \mathrm{L})$ group. Values for $\mathrm{LD}, \mathrm{MD}$ and HD were $136.00 \pm 0.97,133.17 \pm 0.48$ and $135.67 \pm 0.33 \mathrm{mmol} / \mathrm{L}$, respectively Figure 1.

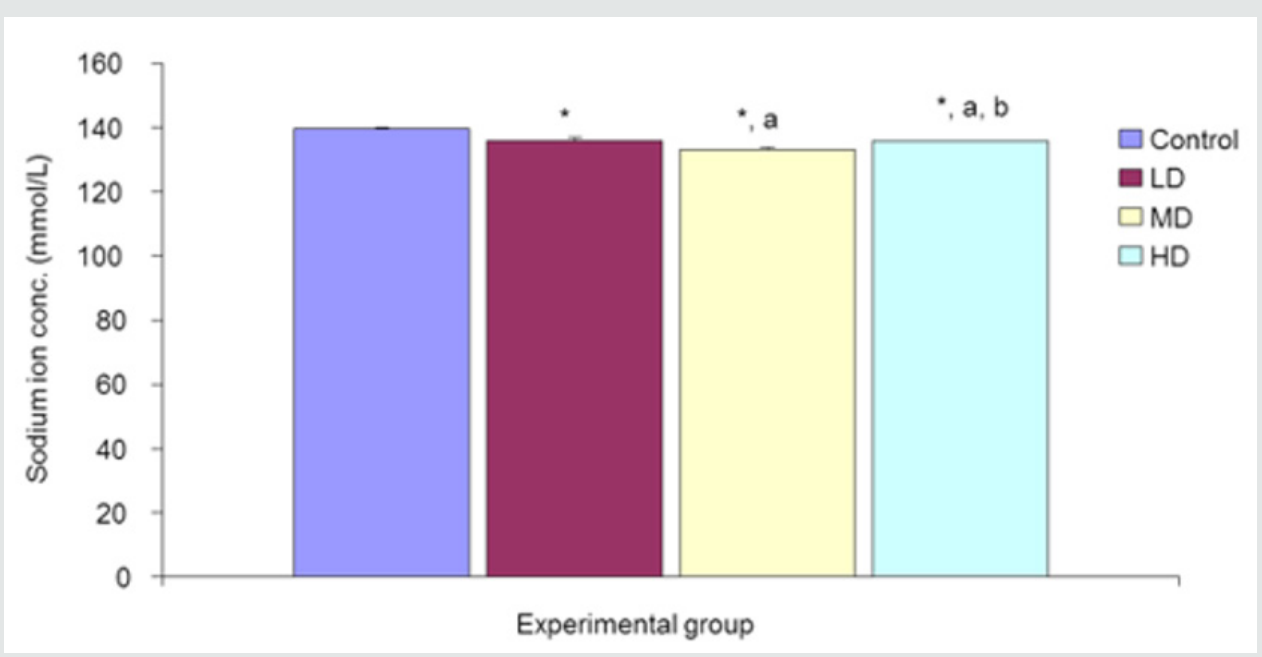

Figure 1: Comparison of sodium ion concentration in the different experimental groups.

Values are expressed as mean + SEM, $n=6$.

*= Significantly different from control at $\mathrm{p}<0.05$.

$\mathrm{a}=$ Significantly different from low dose at $\mathrm{p}<0.05$.

$\mathrm{b}=$ Significantly different from median dose at $\mathrm{p}<0.05$.

\section{Potassium ion concentration $\left(\mathrm{K}^{+}\right)$}

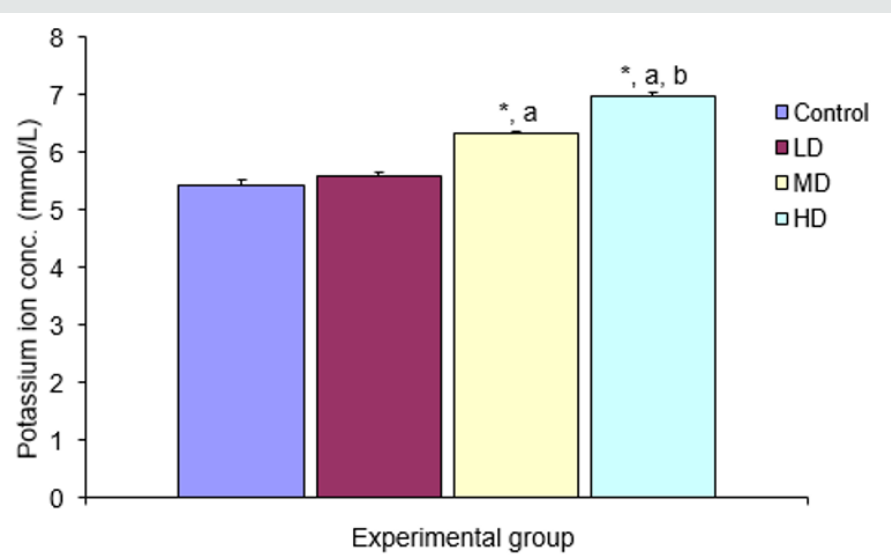

Figure 2: Comparison of potassium ion concentration in the different experimental groups.

Values are expressed as mean + SEM, $n=6$.

* = Significantly different from control at $\mathrm{p}<0.05$.

$\mathrm{a}=$ Significantly different from low dose at $\mathrm{p}<0.05$.

$\mathrm{b}=$ Significantly different from median dose at $\mathrm{p}<0.05$. 
There was significant increase in potassium ion concentration in the groups given medium and high doses of extract when compared with the control $(5.43 \pm 0.08 \mathrm{mmol} / \mathrm{L})$ and low dose $(5.60 \pm 0.06 \mathrm{mmol} / \mathrm{L})$ groups. The group treated with high dose of the extract also showed significant increase in $\mathrm{K}^{+}$concentration $(6.97 \pm 0.07 \mathrm{mmol} / \mathrm{L})$ over the group given median dose. There was however no significant different in potassium ion concentration in the group given low dose of extract when compared with the control group (Figure 2).

\section{Chloride ion concentration $\left(\mathrm{Cl}^{-}\right)$}

The comparison of Chloride ion concentration in the different experimental groups reveals a significant $(\mathrm{p}<0.05)$ decrease in chloride ion concentration in the groups given low, median and high doses of the extract when compared with the control group $(100.83 \pm 0.40 \mathrm{mmol} / \mathrm{L})$. Values for $\mathrm{LD}, \mathrm{MD}$ and HD groups were $96.00 \pm 0.58,97.00 \pm 0.84$ and $95.00 \pm 0.42 \mathrm{mmol} / \mathrm{L}$ respectively Figure 3.

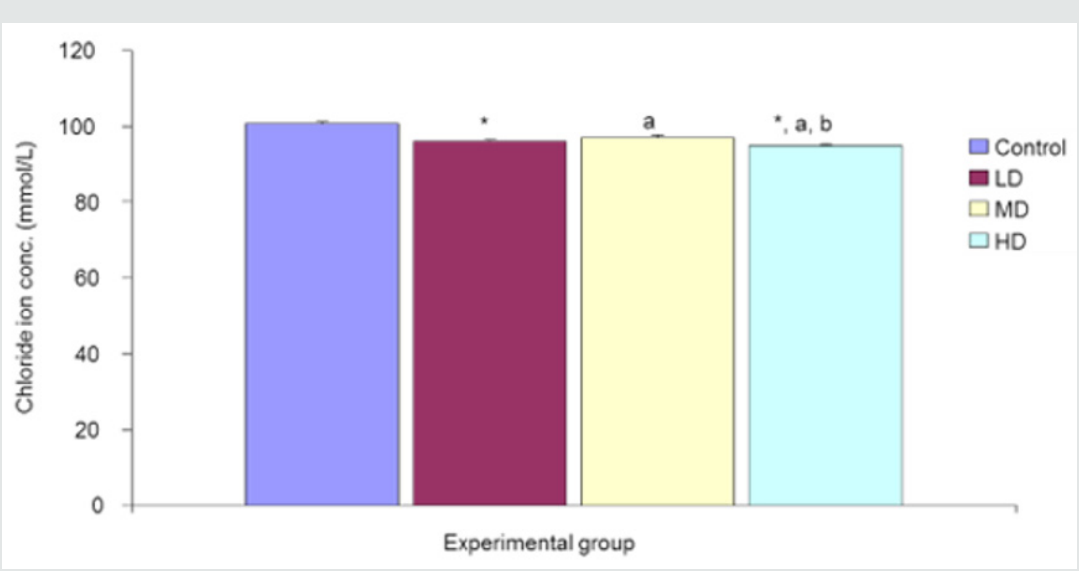

Figure 3: Comparison of chloride ion concentration in the different experimental groups.

Values are expressed as mean + SEM, $n=6$.

* = Significantly different from control at $\mathrm{p}<0.05$.

$\mathrm{a}=$ Significantly different from low dose at $\mathrm{p}<0.05$.

$\mathrm{b}=$ Significantly different from median dose at $\mathrm{p}<0.05$.

\section{Bicarbonate ion concentration $\left(\mathrm{HCO}_{3}^{-}\right)$}

There was significant $(\mathrm{p}<0.05)$ decrease in bicarbonate ion concentration in the groups given median and high doses of extract when compared with control $(21.17 \pm 0.40 \mathrm{mmol} / \mathrm{L})$ and low dose $(21.33 \pm 0.49 \mathrm{mmol} / \mathrm{L})$ groups. The group given high dose $(17.00 \pm 0.37 \mathrm{mmol} / \mathrm{L})$ extract also showed significant $(\mathrm{p}<0.05)$ decrease in bicarbonate ion concentration when compared with the group given median dose $(18.17 \pm 0.31 \mathrm{mmol} / \mathrm{L})$ of the extract Figure 4.

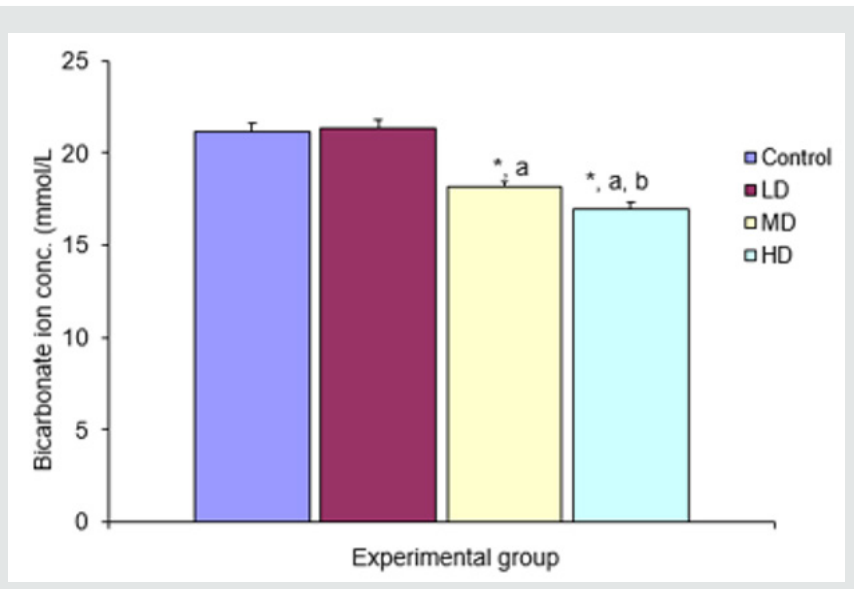

Figure 4: Comparison of bicarbonate ion concentration in the different experimental groups.

Values are expressed as mean + SEM, $n=6$.

* = Significantly different from control at $\mathrm{p}<0.05$.

$\mathrm{a}=$ Significantly different from low dose at $\mathrm{p}<0.05$.

$\mathrm{b}=$ Significantly different from median dose at $\mathrm{p}<0.05$. 


\section{Discussion}

Extract of Desmodium adscendens caused significant decrease in plasma sodium and chloride ions concentration. Serum sodium concentration contributes substantially to blood pressure regulation. The mechanisms by which salt raises blood pressure are not fully understood. The existing concepts focus on the tendency for an increase in extracellular fluid volume. Changes in plasma sodium are the immediate drive to the changes in extracellular volume. However, there is increasing evidence that small changes in plasma sodium may directly affect the hypothalamus, the local renin-angiotensin system, and the heart and vasculature, all of which may play a role in changing blood pressure independent of and additive to that which occurs with the tendency for the changes in extracellular volume. In other words, small increases in plasma sodium may be in part directly responsible for the elevated blood pressure, and vice versa [12]. So, Desmodium adscendens, which causes decrease in serum sodium concentration, will cause a drop in blood pressure. Evidence from monogenic syndromes, dietary and animal studies on renal $\mathrm{Cl}^{-}$balance, and $\mathrm{Cl}^{-}$transporters in vascular tissues point to a critical role for $\mathrm{Cl}^{-}$in mechanisms that contribute to blood pressure regulation. Monogenic syndromes associated with $\mathrm{Cl}^{-}$transporters manifest high and low blood pressure phenotypes. In Gordon's syndrome, hypertension occurs because of increased $\mathrm{Cl}^{-}$reabsorption in the thiazide-sensitive segment of the distal renal tubule [13]. Therefore, any agent that reduces serum concentration of Chloride ion will reduce blood pressure.

The treated groups had significant increase in serum potassium ion levels. This is beneficial, as high potassium helps to lower the arterial blood pressure by stabilizing the resting membrane potential. Potassium helps lower blood pressure by balancing out the negative effects of salt. The kidneys use a delicate balance of sodium and potassium to pull fluid across a wall of cell from the blood stream for excretion [14]. Serum bicarbonate $\left(\mathrm{HCO}_{3}\right)$ level was significantly decreased in the extract-treated groups in this study. The decrease may imply that the $\mathrm{pH}$ of the blood went up. However, this is not to pose any serious problem as the serum chloride concentration also went down. $\mathrm{Cl}^{-}$is the major extracellular strong ion and is key to maintenance of acid-base homeostasis. $\mathrm{Cl}^{-}$ levels are inversely related to bicarbonate, which acts as the major acid-base buffer in humans. $\mathrm{Cl}^{-}$was identified as the primary factor influencing the occurrence of metabolic alkalosis and non-anion gap metabolic acidosis in critical illness. This decrease in $\mathrm{HCO}_{3}$ could be attributed to increased renal excretion of bicarbonate $[15,16]$.

\section{Conclusion}

Desmodium adscendens extract has the potential to reduce high blood pressure in normotensive and hypertensive patients. This potential may be attributed to its phytochemical constituents of flavonoid, alkaloids, tannins, saponins, glycosides, reducing agents, polyphenols, anthraquinones, and phlobatanins.

\section{References}

1. Taylor L (2005) The healing power of rain forest herbs. Square One Publishers: USA, 528.

2. Dierk H Endemann, Qian Pu, Carolina De Ciuceis, Carmine Savoia, Agostino Virdis, et al. (2004) Persistent remodeling of resistance arteries in type 2 diabetic patients on antihypertensive treatment. Hypertension 43(2): 399-404.

3. Huang A, Luethi N, Martensson J, Bellomo R, Cioccari L (2017) Pharmacodynamics of intravenous frusemide bolus in critically ill patients. Critical Care Resuscitation 19(2): 142-149.

4. Luke RG, Galla JH (2012) It is chloride depletion alkalosis, not contraction alkalosis. J Am Soc Nephrol 23(2): 204-207.

5. Haque SK, Ariceta G, Batlle D (2012) Proximal renal tubular acidosis: A not so rare disorder of multiple etiologies. Nephrol Dial Transplant 27(12): 4273-4287.

6. Asano S, Kato E, Yamauchi M, Ozawa Y, Iwasa M (1966) The mechanism of acidosis caused by infusion of saline solution. Lancet 1(7449): 12451246.

7. Shires GT, Holman J (1948) Dilution acidosis. Ann Intern Med 28(3): 557-559.

8. Vaduganathan M, Pallais JC, Fenves AZ, Butler J, Gheorghiade M (2016) Serum chloride in heart failure: a salty prognosis. Eur J Heart Fail 18(6): 669-671.

9. Jessica Kendrick, Leila Zelnick, Michel Chonchol, David Siscovick (2017) Serum Bicarbonate is Associated with Heart Failure in the Multi-Ethnic Study of Atherosclerosis (MESA) American Journal of Nephrology 45(2): 118-126.

10. Trease GE and Evans WC (1984) Pharmacognosy. (12 ${ }^{\text {th }}$ edn), Bailliere Tindal, London, pp. 622.

11. Ohwada K (1986) Improvement of cardiac puncture in mice. Jikken Dodutsu 35(3): 353-355.

12. Feng J He, Nirmala D Markandu, Giuseppe A Sagnella Hugh E de Wardener, Graham A MacGregor (2005) Plasma Sodium. Hypertension 45: 98-102.

13. Machnik A, Neuhofer W, Jantsch J, Dahlmann A, Tammela T, et al. (2009) Macrophages regulate salt-dependent volume and blood pressure by a vascular endothelial growth factor-C-dependent buffering mechanism. Nat Med 15(5): 545-552.

14. Lu Xi, Yong Chen Hao, Jing Liu, Wei Wang, Miao Wang, et al. (2015) Associations between serum potassium and sodium levels and risk of hypertension: A community-based cohort study. Journal of Geriatric Cardiology 12(2): 119-126.

15. Shirley DG, Capasso G, Unwin RJ (2003) Renal physiology. In: R Johnson, J Feehally (Edt.), Principles of clinical nephrology ( $2^{\text {nd }}$ edn.), Mosby International, Philadelphia.

16. Fisher EW (1969) Hydrogen ion concentration-Anion-cation (acid-base) balance. In: Textbook of Veterinary Clinical Pathology, Medway W, Prier JE, Wilkinson JS (Edt.), The Williams and Wilkins Co, Baltimore. 
This work is licensed under Creative Commons Attribution 4.0 License

To Submit Your Article Click Here:

Submit Article

DOI: 10.32474/ACR.2020.02.000150

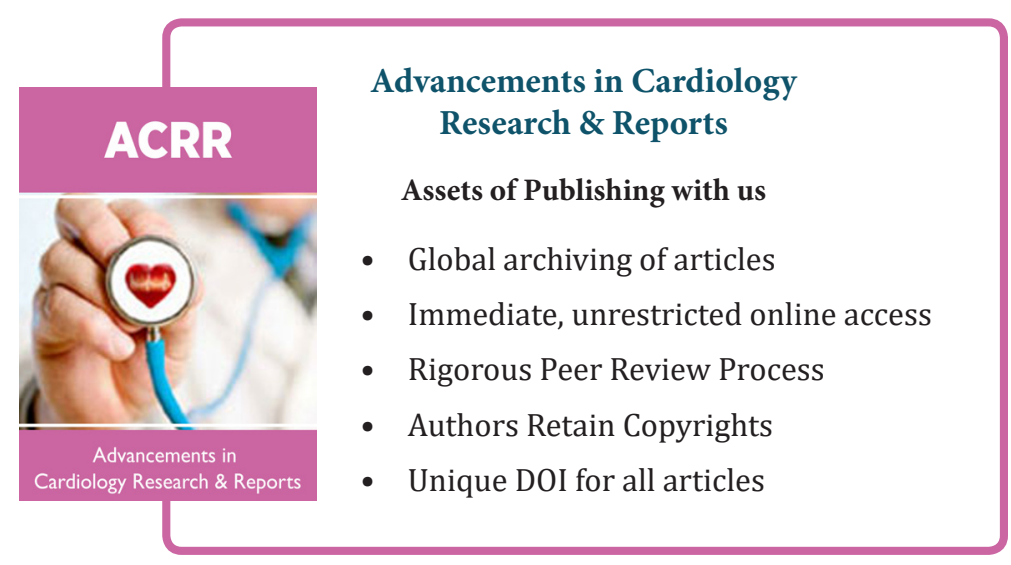

